\title{
ENTREVISTA COM O \\ Professor Franklin Leopoldo e Silva
}

\author{
Por Clélia Ap. Martins \\ Andrey Ivanov
}

Clélia - O senhor poderia falar um pouquinho para nós da sua história de vida, da sua formaçâo, de por que ter escolhido Filosofia?

Franklin - A minha escolha pelo curso de Filosofia se deu no colégio. Quando eu fiz colégio, havia dois tipos de colegial, o científico, que era destinado às pessoas que iam fazer o vestibular em ciências naturais e exatas, e o curso clássico, que era destinado às pessoas que fossem fazer cursos de humanidades. Então, eu me dirigi ao curso clássico, uma vez que em princípio, no primeiro ano, eu tinha intenção de fazer História. Aí, ao longo dos três anos do colegial clássico, eu tive uma professora de Filosofia que acabou me convencendo e a outros da sala a fazer o curso de Filosofia. A minha escolha se deveu quase que inteiramente a essa professora, eu me lembro do nome dela, ela se chamava Dona Selênia, que nos entusiasmava muito com a Filosofia, tendo em vista a maneira como ela dava as aulas, dava o curso; saímos da aula assim com uma grande curiosidade em vários setores de Filosofia. Ela fazia a gente ler Platão, Kant, Heidegger, Sartre, e com isso a gente lia, não entendíamos muito, mas ia despertando assim uma curiosidade, um interesse muito grande e entâo resolvi que faria o vestibular para Filosofia. Então, eu realmente fiz e entrei em 1967 no curso de Filosofia da USP, que ainda era na Maria Antônia. O vestibular era específico naquele tempo, cada curso fazia o vestibular. O de Filosofia era então organizado desta forma: havia uma prova de línguas que era a tradução de um texto filosófico e uma prova de Filosofia, uma dissertação, uma pequena dissertação de Filosofia e, depois, um exame oral que constava também de temas de Filosofia e temas de cultura geral. Entáo, essas eram as provas que se fazia para entrar no curso de Filosofia. Eu fiz isso, passei no vestibular e entre 67 e 71 eu fiz o curso de Filosofia. Até o final de 68, na Maria Antônia, e depois até o final de 71 no campus do Butantâ, para onde a Faculdade foi depois daqueles episódios do entrevero com o Mackenzie e aquela coisa toda 
e terminamos então o curso no campus do Butantã. A minha formação de graduação foi feita dessa maneira.

\section{Clélia - Então o senhor sempre teve claro que era Humanas mesmo?}

Franklin - Sim, sim. Desde antes do colégio mesmo eu tinha uma certa antipatia e dificuldades também, naturalmente uma coisa provocava a outra, com disciplinas que não fossem de humanidades. Daí ter escolhido o clássico, em que a maioria das disciplinas era de humanas; havia umas pinceladas de Física e outras coisas, mas o essencial mesmo, o centro do curso era Latim, História, Filosofia, Geografia e a Língua e Literatura Portuguesa. Eu me dava bem com essas disciplinas, sempre me dei bem, e fiz o clássico nessa direção, com alguma dificuldade, tendo em vista que por injunções familiares eu fiz todo o ginásio em colégio particular e na minha época, ao contrário do que ocorre hoje, os colégios particulares eram muito fracos, muito fracos, e os colégios estaduais eram muito exigentes. Eu sofri um pouco com isso, mas a minha família, que tinha certos preconceitos de caráter social e religioso, fazia questão que eu estudasse em colégio particular, o que prejudicou muito a minha formação, porque não se aprendia nada. Então, eu mesmo, por minha conta, me matriculei no colégio estadual e na primeira aula eu percebi qual era a minha condição, ou seja, atrás de todo mundo: a maioria dos que estavam ali havia feito a formação deles toda em colégio do Estado, e eles sabiam tudo o que eu não sabia, por exemplo, Literatura; perguntaram pra mim: "O que você leu?” e eu só tinha lido coisinhas insignificantes. Machado de Assis e essas coisas assim eu não conhecia e eles já estavam há muito tempo familiarizados com isso. Eu tive que me esforçar muito para me colocar junto com isso e consegui acompanhar o curso que era muito exigente, com professores excelentes em todas as disciplinas, professores que a maioria depois veio a trabalhar na USP, e mesmo aqueles que não vieram poderiam perfeitamente estar em qualquer universidade, a exigência era muito grande. Então, eu pude entrar na USP, em Filosofia. Fiz cursinho, mas nem precisava fazer, fiz mais por um reforço, porque era plenamente suficiente naquela época o que a gente aprendia no colégio para passar no vestibular e se encaminhar mais ou menos, com uma certa familiaridade com algum assunto, pela graduação.

Clélia - O senhor fez a graduação nesse periodo, entre 67 e 71, um periodo bastante conturbado da história, inclusive da história da universidade pública brasileira. O senhor poderia falar um pouquinho disso e depois, na sequência, como o senhor compreende a sua inserção dentro da universidade na parte administrativa, sua participação burocrática. Vimos no seu currículo que o senhor ocupou cargo de 
secretário do Conselho de Departamento, vice-chefe de Departamento, presidente de comissão de reestruturação da própria Faculdade de Filosofia, Letras e Ciências Humanas, da comissão setorial de avaliação também da própria Faculdade. Então, essa parte, como aluno que viveu um periodo conturbado da história, entrou na universidade e fez parte de comissóes de reestruturação, de avaliação e também dos cargos normais da esfera burocrática da universidade, como o senhor baliza isso?

Franklin - Eu realmente entrei numa fase bastante complicada e também de uma certa transição, no perfil do movimento estudantil, do perfil político do movimento estudantil. Havia até meados da década de 60 um domínio do Partido Comunista, o Partidão, que era mais ou menos em continuidade com aquele que havia antes do golpe de 64. Eles dominavam praticamente na esquerda e na universidade também o movimento estudantil, no que havia assim de oposição de esquerda, era assim conduzido basicamente pelo Partido Comunista. Lembro-me que o Centro Acadêmico, quando eu entrei, era presidido pelo Partido Comunista, o que já estava acontecendo há muitos anos, não havia renovação. Começou assim aquilo que depois foi dar no movimento estudantil em 68 e 69, que é a proliferação de movimentos e grupos políticos que contestavam a hegemonia do Partidáo. Começou a aparecer aquela infinidade de grupos pequenos e que tinham linhas de atuação política muito diferentes. Isso foi se avolumando e o partidão acabou por perder assim de uma maneira bem inesperada; os comunistas sempre foram muito confiantes em si mesmos, eles não esperavam que fossem desalojados de parte alguma, entáo, eles estavam tranquilos mesmo quando viam que a coisa não ia crescendo, e acabaram as chapas tanto para o Centro Acadêmico quanto para o DCE e para a UNE. Essas chapas acabaram criando dentro do movimento estudantil um número enorme de simpatizantes e com isso houve essa renovação. Eu passei então por essa fase, assisti a essa mudança de perfil, mas sempre também junto com muita repressão. Uma das causas pelas quais o Partido Comunista foi substituído nas funçôes que ele desempenhava na condução do movimento foi exatamente essa maneira que eles tinham de reagir às coisas que aconteciam de uma maneira que era considerada, por muitos, como náo suficiente e, portanto, esses outros grupos acabaram tomando o poder em várias instâncias do movimento estudantil, conduzindo-o para outros caminhos que eram mais de confronto com o governo, com o governo militar. E, em 68, isso se exacerbou, foi um ano característico dessa exacerbação, de muita repressão e com esse episódio simbólico do entrevero que houve lá com o Mackenzie, o incêndio da Faculdade de Filosofia, do prédio que ficava na 
Maria Antônia e o fato de termos sido desalojados e encaminhados para a Cidade Universitária, onde já funcionavam alguns cursos.

Essa minha experiência política bastante curta se desenvolveu nesse sentido, ali com os meus colegas da Faculdade de Filosofia, que formavam um contingente muito grande e muito variado, porque até a reforma universitária, que aconteceu em 69/70, a Faculdade de Filosofia congregava todos os cursos, com exceção de Medicina, Engenharia, Direito e Agronomia. Todos aqueles cursos que hoje constituem os Institutos de Ciências Básicas estavam na Faculdade de Filosofia. Portanto, havia uma convivência muito forte e politicamente muito produtiva entre as pessoas de várias áreas, convivência que para esse fortalecimento do movimento ao qual correspondeu naturalmente o fortalecimento da repressão até esse episódio de $68 \mathrm{em}$ que as coisas foram bastante desmanteladas e prejudicadas, tendo em vista a mudança da própria situação geográfica. Quer dizer, o fato de a Faculdade de Filosofia ser um centro irradiador do ponto de vista político e cultural se devia em parte a sua localizaçáo. Ela substituiu meio que a Biblioteca Municipal dos velhos tempos como centro de cultura, congregava também politicamente as pessoas e a saída dali foi desastrosa nesse sentido, porque naquele tempo a Cidade Universitária, situada ainda muito longe do centro da cidade, era realmente um gueto, de difícil acesso, com pouco contato com a população, não era como hoje, um bairro normal, naquele tempo era tudo muito afastado e isso contribuiu muito para o isolamento dos estudantes, dos professores e, portanto, também do movimento estudantil, que então teve que se abrir para outras perspectivas no sentido de prosseguir a sua ação.

A minha experiência foi nesse período, mais ou menos por aí. Nunca pertenci a nenhuma tendência política, eu sempre me mantive independente, não por achar que não deveria pertencer a alguma coisa, até tinha intenção de fazer isso, mas nunca tive a oportunidade suficiente de fazer uma escolha, uma opção, e também ser aceito pelos grupos existentes, tendo em vista que provavelmente meu perfil, minha visão pessoal das coisas não coadunava com o que era frequente nesses grupos, muitos dos quais eram bem dogmáticos. Mas mesmo assim exerci vários cargos no movimento estudantil e no Centro Acadêmico. Pelo menos por três anos fui membro da diretoria do Centro Acadêmico. Sintomaticamente com tendências diversas, como eu não pertencia a nenhuma, eu me sentia à vontade e também os outros se sentiam à vontade para me chamar para colaborar. Isso nem sempre causava boa impressão, mas fiz o que pude e creio que desempenhei um certo papel, porque na época da 
repressão as pessoas que ocupavam esses cargos e ao mesmo tempo pertenciam a partidos políticos eram muito visadas e várias vezes tinham que desaparecer por motivos óbvios e eu ficava então encarregado meio que burocraticamente da gestão do Centro Acadêmico, às vezes sozinho, tendo em vista que as pessoas que eram realmente importantes politicamente não podiam ficar ali à vista, principalmente depois de 68 . O que aconteceu em 71, depois do Ato Institucional, eu já era professor, já vivia de outra forma.

Sobre a minha atuação administrativa depois que me tornei professor, de fato exerci vários cargos, inclusive de chefe de Departamento, fui assistente de chefia, um cargo que hoje não existe mais, fui secretário do Departamento, um cargo que hoje está senão formalmente mas na prática extinto. Depois participei de várias comissóes, fui Coordenador de Pós-Graduação e fui também chefe e vice-chefe de Departamento; além de comissóes no âmbito da Faculdade das quais eu participei de várias delas e também fui membro da Congregação e também, não sei se isso se enquadra num cargo, tenho a impressão que não, não é exatamente um cargo burocrático, uma função, fui representante dos doutores no Conselho Universitário por volta de 86/87. Então, em todas as instâncias, departamento, faculdade e universidade, eu exerci alguma função de representação ou de caráter administrativo. Isso se deve a uma certa, não digo facilidade, mas uma certa anuência, não sei como dizer, não é facilidade, nem vocação. Enfim, eu conseguia fazer o trabalho administrativo de uma forma que não me perturbava tanto e principalmente não perturbava os outros. Entáo, eu era meio que instado a assumir esses cargos, porque eu conseguia levar as coisas com relativa eficiência e do ponto de vista digamos assim da política interna do departamento eu meio também que não deixava que os conflitos não se exacerbassem, ia contornando as coisas através de negociaçóes e tal e conseguia, digamos assim, na maior parte do tempo, contentar as pessoas. $\mathrm{Na}$ vice-chefia e na chefia foram pelo menos em quase duas gestôes em que essas coisas ocorreram e eu desempenhei essas funçôes. Tendo em vista essa eficiência no Departamento, fui chamado para exercer funções semelhantes no âmbito da Faculdade como presidente de comissão e assim por diante. Atuei bastante na Congregação em épocas complicadas também, e a principal comissáo da qual eu participei julgo que tenha sido essa chamada de reestruturação que na verdade era para decidir algo que agora voltou à baila lá na Faculdade de Filosofia, que é a separação da Faculdade em Departamentos e institutos, tendo em vista o tamanho e as dificuldades operacionais e administrativas que a Faculdade enfrenta, devido ao seu tamanho. Ela já foi muito maior, nós sabemos que antes de 69/70, 
antes dessa reforma universitária, congregava todos os cursos com exceção dos profissionais, depois passou a ser só Filosofia, Letras e Ciências Humanas e aí, durante esse período, que agora não sou capaz de me lembrar exatamente o ano, houve uma primeira ideia de desmembrar a faculdade, tendo em vista uma melhor organização burocrática e administrativa.

Mas a discussão naquela época tinha muito conteúdo político que consistia no seguinte: como vocês sabem, o projeto de fundação da USP previa que a Faculdade de Filosofia, Ciências e Letras, como se chamava na época, fosse uma espécie de centro irradiador em termos de cultura justamente para dar à universidade um perfil não profissional, que não acompanhasse a tendência das grandes escolas profissionais que certamente exerceram grande influência na própria universidade, mas para contrabalancear isso, o próprio Fernando de Azevedo, os Mesquita e os fundadores da USP imaginaram uma faculdade em que as ciências básicas e as humanidades permitissem uma formação não profissional que eles achavam importante e não existia na época.

A Faculdade foi formada assim, depois ela se desmembrou, os institutos de ciências se separaram e aí havia a ideia de que esse papel político já estava superado, até pelo fato de que ela nunca o cumpriu corretamente. Mesmo depois que a USP foi montada e a Faculdade de Filosofia foi colocada em seu centro, o poder de decisão sempre esteve com as profissionais, nunca a Faculdade de Filosofia teve qualquer tipo de influência nos rumos da Universidade, apesar de ela ser a principal unidade. Então, ela exerceu seu papel mais do ponto de vista cultural e acadêmico do que propriamente político e administrativo. E nesse caso o pessoal achava que estava superado, que era um idealismo dos fundadores, que não havia como continuar, que a saída da Maria Antônia tinha sido uma coisa muito simbólica. Uma professora colega minha que se batia pela separação e que sempre se encontrava comigo ali no prédio novo do Butantã, no campus, me dizia assim: "Franklin, lembre-se que a Maria Antônia não mora aqui”. Mas eu então fui chamado, dadas essas ideias que eu tinha de que devia manter a unidade, ainda havia alguma coisa a fazer, nesses termos, fui chamado para presidir essa comissáo de reestruturação que era então dividida em duas - uma comissão que trabalhava o projeto de separação e a outra trabalhava a manutenção da unidade -, e eu era o presidente dessa da manutenção da unidade. Fizemos uma grande pesquisa, argumentos, produzimos muitas reunióes e argumentos políticos, dados estatísticos. Lembro-me até de ter ido à POLI, que é maior que a Faculdade de Filosofia, entender como eles trabalhavam, o que foi uma coisa interessante para o nosso 
argumento, uma vez que a POLI conseguia resolver seus problemas muito bem, não pensavam em se separar, achavam pelo contrário, que estava tudo muito bem daquela maneira. Tudo dependia de você montar uma organização administrativa que desse conta do recado, coisa que eles podiam fazer, porque eles tinham dinheiro e nós não. Enfim, não era um caso extraordinário, não era por natureza que devia se separar; então, a Congregação, levando em conta os argumentos dos dois lados optou pela manutenção da unidade, depois houve mais uma vez essa mesma tentativa que também se decidiu pela manutenção da unidade e agora pelo que eu ouço, eu ando meio afastado da discussão, voltou de novo essa ideia e, ao longo da gestão atual que começou há pouco tempo da diretoria recém-nomeada, está previsto que se decidirá a separação ou não da Faculdade tal como ela está estruturada agora. Entáo, eu participei de várias comissóes burocráticas, mas essa eu considero a mais importante, porque além da burocracia propriamente dita, dos dados, das informaçóes e planejamento etc., havia também essa discussão política, que eu não sei se continua ainda, da conveniência da manutenção da Faculdade ou de seu desmembramento em vários institutos.

Com o passar das geraçóes e a dificuldade de manter na memória o projeto de universidade inicial e o papel da Faculdade de Filosofia, é claro que essas questóes tendem a ser vistas de uma outra forma, os critérios para se decidir serão de uma outra maneira. Mas, em todas essas instâncias que passei, quando eu exerci cargo administrativo, sempre senti as dificuldades inerentes ao tamanho da Faculdade e a falta de estrutura administrativa para manter aquilo tudo em funcionamento, muitas dificuldades de todo tipo. Como eu era o chefe de Departamento, eu estava muito próximo da diretoria, eu sentia muito essas dificuldades no nível de diretoria de faculdade mesmo e tal, mas também sempre achei que devia ser preservado um certo sentido da Faculdade onde reside, digamos assim, um espírito universitário. É muito possível que, se a Faculdade viesse a ser desmembrada e esse espírito universitário vai se dispersar, ao longo daquilo que o Florestan Fernandes chamava de um conglomerado de escolas. As universidades no Brasil tendem a ser um conglomerado de escolas e não propriamente uma universidade, porque não têm um centro que projete uma certa unidade acadêmica. A Faculdade de Filosofia deveria ter esse papel e precariamente ela tenta fazer isso muito longe de qualquer tipo de, digamos assim, êxito, pois as circunstâncias militam contra, mas ainda assim hoje eu acredito que, se tivesse que votar ou participar da decisão, ainda insistiria um pouco mais na unidade da Faculdade para ver o que se pode fazer a respeito. Eu acho um assunto importante, por isso eu acho que o trabalho que eu fiz 
nessa comissão, do ponto de vista de todas que eu participei, foi o que eu considero mais importante, mais significativo.

Andrey - Poderia nos falar sobre como o senhor concebe a Filosofia e sobre o estado da Filosofia ontem e hoje?

Franklin - Sim. Então, quando eu falo desse assunto, em geral, eu me decepciono. Há vários episódios que mostram isso porque, na verdade, eu participei de uma geração que foi formada para ser professor de História da Filosofia e não filósofo, o que era uma coisa que na época pra gente era até divertido, a gente não devia ter essa pretensão, não deveria usar esse título e, também, no meu caso particular e dos meus colegas, nem mesmo professor de Filosofia e sim professor de História da Filosofia e os nossos mestres, Giannotti, Bento, Ruy e Porchat, que foram os formadores do Departamento, insistiam muito nisso, nesse distanciamento crítico, nessa ausência de pretensão ao filosofar, contra o qual a Faculdade havia sido constituída, contra aquilo que o Professor Ruy Costa chamava de filósofos municipais.

Antes dessa Faculdade havia uma série de intelectuais, talvez entre aspas, que escreviam livros sobre o tempo, a causalidade, o universo, e quando a Faculdade de Filosofia chegou nessas condiçóes, a primeira coisa que o Ruy Costa diagnosticou foi que aquilo não queria dizer nada, era uma caricatura e que, portanto, precisava formar uma coisa mais rigorosa, mais acadêmica, com uma certa lógica de pesquisa que viesse a subsidiar aquelas elucubraçóes. E o curso de Filosofia foi formado com essa intenção, os professores que vieram tinham esse objetivo e, portanto, tudo isso acabou gerando o famoso estruturalismo do Departamento de Filosofia, a leitura dos textos filosóficos com um certo distanciamento, uma certa objetividade, um certo rigor interno e a exposição disso na maneira mais real possível, sem qualquer pretensão de você colocar no meio daquilo qualquer tipo de vivência ou experiência ou de vida ou de pensamento que fosse além, aquela informação deveria ser transmitida de forma mais organizada possível aos alunos. O Gueroult, o Goldschmidt, os grandes patronos dessa atitude, tiveram no Departamento os seus representantes e o Departamento então se imbuiu disso, entendendo que haveria a necessidade de passar por essa disciplina, a fim de que houvesse realmente Filosofia no Brasil, no sentido acadêmico e não simplesmente no sentido amador; com isso, a minha geração ainda foi muito influenciada por essa atitude e nós fomos formados nesse sentido. Em relaçáo aos meus colegas que fizeram o curso comigo e se tornaram professores comigo não sei o quanto eles conservam esse tipo de atitude, mas a mim me marcou muito 
e eu não consigo fazer outra coisa, quer dizer, faço de uma maneira cada vez mais flexível, porque já não tenho mais a cabeça estrutural para fazer análises filosóficas como fazia há vinte anos atrás; hoje faço de uma maneira mais flexível, digamos assim, mais modesta, mas continuo fazendo História da Filosofia e com muita consciência da especificidade disto que é portanto algo diferente de uma reflexão filosófica sobre temas de filosofia. Sempre que me pedem para fazer isso, eu faço da seguinte maneira, está muito na moda falar sobre ética, e quando me solicitam: "Escreva um texto sobre ética", eu escrevo o que eu acho possível e necessário que é falar das teorias éticas, vou a Platáo, Aristóteles, Kant, e às vezes o pessoal me diz: "Mas isso não é ética, eu quero que você fale da ética”, mas aquele é a única maneira que eu sei fazer isso. Há muitos episódios que contrariam um pouco essa posição que na USP foi muito forte. Nos cursos que se fizeram a partir da USP, meio que à imagem da USP, isso aconteceu também, mas em muitos outros não, e como eu já percorri muitos cursos de Filosofia no Brasil, fui dar aula em alguns deles, e senti essa diferença. Nunca me esqueço de um curso que eu dei no Nordeste sobre Kant e Leibniz para um curso de mestrado e aí no final das contas os alunos me perguntaram: "Muito bem, agora que já terminaram as aulas, a gente quer saber quem você acha que está certo, é o Leibniz ou é o Kant?” Aí eu falei que, em primeiro lugar, eu não saberia dizer, mas também não me preocupo com isso. Eles ficaram horrorizados e porque para eles isso quer dizer que você náo se preocupa com a verdade porque, se você se preocupasse com a verdade, você tentaria dizer se a verdade está com um ou com o outro; então, você faz filosofia, mas não se preocupa com a verdade, o que é um paradoxo. Eu realmente senti essa diferença de enfoque, mas, digamos assim, foi o nosso treinamento. Hoje em dia, eu acho que isso não está mais tão forte no Departamento por conta do tempo que se passou, por circunstâncias intelectuais, acadêmicas, políticas, por uma certa história que aconteceu e que fez com que isso fosse mudando, ao longo das geraçóes. Está ainda bastante presente, eu vejo, nos professores mais jovens, na maneira como eles se manifestam, quando eu os encontro dando aula em outros lugares, eu percebo ainda aquela formação de história, do rigor da leitura dos textos, aquela coisa toda, mas é claro que isso já assumiu um certo significado que eu acho saudável.

O Paulo Arantes costuma dizer uma coisa que eu acho interessante, ele diz que toda aquela formação rigorosa do ponto de vista de você assimilar a Filosofia enquanto história, pensamento, da forma mais objetiva e rigorosa possível, aquilo era uma preparação, e não uma finalidade em si, mas uma preparação que as circunstâncias não permitiram que florescesse, ou seja, 
um processo que não chegou a dar os seus frutos devido às circunstâncias políticas. Ele acha, a partir do que aconteceu em 64, do golpe e da repressão à universidade, a dispersão fez com que essa preparação para a filosofia se tornasse uma finalidade em si, que não havia outra coisa a ser feita, foi assim uma espécie de refúgio. Isso prejudicou na verdade o grande projeto que seria do Ruy Costa e de outros mais velhos, uma vez que você, tendo adquirido essa preparação filosófica, teórica rigorosa, você poderia atuar como filósofo e como político com bases claras, sabendo o que estava fazendo. Então, essa parte, digamos assim, que seria o deslanche da coisa, o resultado da coisa, náo chegou a acontecer. Eu fui muito influenciado por isso e ainda hoje vejo a Filosofia dessa forma. Não discordo de quem a faça de outra maneira, porque acho que hoje em dia há a possibilidade de se fazer isso justamente devido a essa preparação que aconteceu na consolidaçáo do Departamento, mas eu continuo ainda bastante preso a essa perspectiva que é bastante histórica. Portanto, eu sempre me defino assim. A minha relação com a Filosofia é exclusivamente a de professor de História da Filosofia e, portanto, não tem Filosofia, eu não faço Filosofia. Uma vez uma amiga minha me advertiu do seguinte: "Repare bem que dificilmente você começa uma frase que não seja com essa expressão 'segundo o fulano' e isso deixa as pessoas curiosas e depois de 'segundo o fulano' será que vem alguém? Alguma outra coisa?”. Não, para mim não, porque eu acho que a minha função é essa. Então, o que eu penso de Filosofia é isso.

Vejo uma grande diferença de quando eu era estudante para hoje, mas também vejo a conservação, já não na mesma intensidade, dessa perspectiva histórica que eu acho importantíssima, acho muito importante as razóes pelas quais ela foi instaurada e que o aluno passe por isso, embora a gente saiba que às vezes o aluno se impacienta um pouco com essa formaçáo histórica, ele quer logo partir para outras iniciativas, mas isso é importante. Uma coisa que também chama a minha atenção hoje em dia na formação dos alunos, dos professores mais jovens, é uma certa tendência à especialização que eu vejo como um enfraquecimento da formação histórica. Quer dizer, o passar pela História da Filosofia não é você saber bem somente um filósofo, é você poder relacionar aquele autor com vários outros que você também conheça razoavelmente bem independente de decidir, como me pediram no curso ministrado no Nordeste, que eu decidisse quem estava com a verdade e quem não, mas, enfim, relacionar para que as coisas proporcionem uma compreensão recíproca. $\mathrm{Eu}$ sempre digo isso aos meus alunos que é impossível você saber bem um autor, se você não sabe nenhum outro, você vai passar a vida inteira estudando um 
autor, mas, se você não estudou outros, não sabe nem aquele, apenas julgará que sabe, porque há um esclarecimento recíproco. Então, eu vejo que isso, devido às pressóes que as pessoas sofrem hoje em dia para fazer mestrado e doutorado, está um pouco desaparecendo por causa dessas circunstâncias. Vejo na USP que os alunos mais jovens já no final do primeiro ano, segundo ano já tentam estruturar uma pesquisa, já tentam ver um norte ali, alguma coisa na qual eles possam centrar força, pois sabem que eles terão pouco tempo para completar aquilo e depois fazer um doutorado que terá que ser na mesma linha. O horizonte histórico está um pouco diminuído e tende a ser visto como ecletismo, mas não é ecletismo, são elementos variados que você tem que juntar até para poder entender melhor o filósofo da sua predileção, da sua especialidade. Entender o contexto histórico e filosófico é muito importante, o contexto das ideias, acho que isso está um pouco em desuso, mas não culpo ninguém, culpo as circunstâncias, quer dizer, ninguém não, culpo o governo, as autoridades educacionais que promoveram esse estreitamento da pesquisa e fizeram com que as pessoas sejam obrigadas a se mover de maneira apressada e, portanto, numa linha mais definida sem poder para ampliar um pouco a sua trajetória. Isso eu julgo complicado para a Filosofia, que ela tende a seguir essa tendência contemporânea da especialização, não sei se funciona nas outras ciências, provavelmente funciona, é um fator de produtividade e progresso, mas na Filosofia, no meu entender, ele tende a ser um fator de estreitamento do entendimento da Filosofia, da compreensão filosófica e, portanto, dos resultados que as pessoas podem produzir a partir daí.

Andrey - Qual sua opinião sobre a disciplina Filosofia no ensino médio e sobre a formação filosófica na universidade? Qual a relação com políticas públicas?

Franklin - Durante a minha vida acadêmica no Departamento de Filosofia, participei de muitas iniciativas que diziam respeito à Filosofia no segundo grau. O Departamento, durante um certo tempo, se preocupou muito com isso, não só com campanhas pela volta da Filosofia mas também com a reciclagem, o aprimoramento e a preparação de professores de Filosofia do segundo grau, aqueles que já atuavam e aqueles que estavam para entrar nessa condição. Como a Filosofia foi banida do colégio, do ensino do segundo grau, a partir do golpe de 64, essa situação foi se tornando cada vez mais precária, a Filosofia foi cada vez mais desaparecendo do ensino público e permaneceu apenas em alguns colégios particulares que insistiram um pouco em manter a disciplina, mas, digamos assim, numa condição secundária e muito precária em termos de ensino e até mesmo de recrutamento de professores, isso com 
algumas exceçôes de alguns colégios que conseguiram manter um nível bom, mas a maioria não foi por esse caminho, não pôde ir por esse caminho. Essa precariedade sempre se apresentava e o Departamento de Filosofia procurava colaborar dando cursos, fazendo discussóes, convênios com órgãos da Secretaria da Educação, no sentido de tentar interferir um pouco no processo.

Depois que a Filosofia voltou como optativa, como eletiva, antes de voltar agora como obrigatória, nós também continuamos com esse trabalho que foi por razóes burocráticas, eu acredito, arrefecendo o seu ritmo e a própria Secretaria de Educaçáo construiu seus meios próprios de lidar com esses problemas, náo procurou mais a Faculdade de Filosofia. Na universidade, a colaboração ficou por conta da Faculdade de Educação. Antes, havia um certo concerto, uma certa colaboração da Filosofia com a Educação, com os órgãos oficiais. Lembro-me de que havia comissóes em que participavam professores dessas áreas, além do pessoal próprio da Secretaria, mas isso foi enfraquecendo e hoje eu creio que não exista mais, a nấo ser assim de uma maneira muito aleatória e por iniciativas muito mais pessoais ou de grupos do que propriamente do Departamento ou da Secretaria da Educação. Então, o que a gente nunca conseguiu superar no sentido de obter uma fórmula de relativo sucesso foi exatamente a maneira pela qual o professor do segundo grau deve dar as suas aulas. Havia muita discussão a respeito, havia um certo choque de experiências. Eu, por exemplo, e muitos de meus colegas nunca demos aula no segundo grau, fomos dar aula diretamente na universidade; faltou para nós essa experiência do segundo grau, embora num certo momento da universidade, nos meados de 70 e início dos 80 , você tinha os alunos iniciantes do curso de Filosofia e de outros cursos numa situação muito semelhante àquela que provavelmente existia no segundo grau, que era quase que o grau zero de requisitos do estudante.

Ora, como superar essa situação? Nunca conseguimos chegar a uma solução e esse choque de experiências fazia com que nós não pudéssemos indicar, além de alternativas teóricas, alternativas práticas e pedagógicas que nos eram solicitadas. Você pode fazer um belo seminário sobre um tema, um autor, indicar as maneiras pelas quais pode se transmitir aos alunos, agora, a prática da sala de aula efetiva é outra coisa e essa distância nós nunca conseguimos transpor. Algumas pessoas que eu às vezes até reencontro dizem que aquilo foi importante para que eles mesmos pudessem chegar a uma certa estratégia de envolver os alunos com a Filosofia, o que parece bastante difícil no colégio. Então, houve uma participaçáo eu diria até que significativa do Departamento, 
da maioria de seus professores. Nisso, escrevemos livros, muitos artigos, apostilas, sugestóes, mas nunca conseguimos realmente atingir a efetividade do problema, quer dizer, aquela situação em que o professor de Filosofia no segundo grau bem formado ou mal formado está sozinho diante dos alunos e aí ele tem que resolver o que ele faz. Nisso, nós nunca conseguimos ser de grande valia e hoje, com a volta da Filosofia e a participação do Departamento na Licenciatura (pelo novo regulamento, agora o Departamento de Filosofia participa da Licenciatura com disciplinas e atividades além da Educação), essa situação está também voltando à baila, quer dizer, o que fazer para preencher essa tarefa, desempenhar essa tarefa que nos foi dada agora que é participar da preparaçáo do professor mesmo do segundo grau, da Licenciatura. A Educação não faz mais isso sozinha como durante muito tempo aconteceu, agora os departamentos têm também que dar sua parte e nós estamos fazendo isso lá na Filosofia, História da Educação, Filosofia da Educação, enfim, mantendo dentro do espírito filosófico um certo vínculo com essas questóes pedagógicas. Eu tenho a impressão de que essa relação vai dar frutos, novos professores que tiverem que lidar com esses problemas vão conseguir, melhor que o pessoal da minha geração, encurtar essa distância entre universidade e o colégio que sempre foi a intenção até política do Departamento, mas nunca conseguiu, isso nunca aconteceu, as circunstâncias eram bastante desfavoráveis. Agora, creio que isso tem como acontecer, tem circunstâncias favoráveis do ponto de vista legal, acadêmico, histórico e até político. Provavelmente virão momentos em que a Universidade será chamada para colaborar na área de Filosofia, como já acontece nas línguas etc. As outras áreas da Faculdade de Filosofia têm longa experiência eficaz de fazer esse trânsito entre a sala de aula do colégio e a universidade, a História, a Geografia, Português, elas têm essa tradição básica, mas nós não, nós nunca nos demos muito bem com isso, mas eu penso que agora há condições para que essa relação melhore.

Clélia - Então, agora vamos passar às publicaçôes. Nós vimos também que o senhor tem artigos em Bioética, Ética, questão animal, técnica, o biofilho, póshumano, religião e sociedade pós-secular. Como pensar esses temas ou a Filosofia diante desses temas que não são tão especificos da História da Filosofia, é temática bem contemporânea, quase que interdisciplinar?

Franklin - Pode parecer paradoxal. Talvez até como uma reação interna, digamos assim, quase que de personalidade, a essa minha dedicação à História da Filosofia. Eu sempre tentei atender a certos convites de colaboração com áreas que, fora da Filosofia, pudessem tirar proveito de algum tipo de discussão 
interdisciplinar, mas sempre levei para essas discussóes a História da Filosofia, o que muitas vezes decepciona aqueles que me convidam, porque eles gostariam de ouvir falar de Filosofia mesmo no sentido de um pensamento que se desenvolve acerca de algum assunto e não de autores, que é uma coisa meio chata. Eu, porém, procuro mostrar para eles que uma coisa depende da outra e é importante entender como os diversos autores desenvolveram as suas teorias, para que você até entenda que o que você faz na sua prática profissional tem muito a ver com aquilo, mas você não sabia. Isso acontece com áreas mais próximas, por exemplo, eu faço muitos seminários com psicanalistas e volta e meia eles dizem: “Poxa!”... Mas, no caso de Bergson, no caso de Kant, outro dia eu estava falando da apercepção transcendental que em princípio não teria muito a ver e eles conseguiram dizer: "Poxa, mas realmente existe aí um lado oculto que você não pode definir mas que, no entanto, atua como sujeito e tal". Isso aparece muito na relação psicanalítica e eles vão descobrindo as coisas, até mesmo sem eu dizer; você expóe e eles fazem as relações, isso é interessante, aí eu escrevo alguma coisa nesse sentido, quando me é solicitado.

No caso da Bioética, eu estou trabalhando nisso há muitos anos, primeiramente por um motivo, digamos assim, de ordem política. Havia há muitos anos atrás, coisa de 15 anos atrás, talvez até mais, um grupo na Faculdade de Medicina que se preocupava com a ética médica, que, na medicina até relativamente há pouco tempo atrás, era sinônimo de deontologia, quer dizer, Medicina legal, que se fazia separado, perto do necrotério, que é coisa de médico legista. Então, os médicos propriamente ditos que fizeram Medicina importante não tinham preocupação com isso, eles achavam que isso não é uma coisa com que cientista deva se preocupar. Mas havia um grupo lá meio dissidente que queria introduzir essas reflexóes, promover esses temas através de cursos de extensão, discussōes, através dos conselhos que eles têm, o Conselho Federal, o Conselho Regional, que são levados a ver esses assuntos porque recebem denúncias e são levados a refletir sobre isso, queiram ou não queiram. E eles não têm base nenhuma para isso; daí, eles começaram a convocar o pessoal da Filosofia e eu comecei a participar através de um grupo da Faculdade de Medicina que é o Departamento de Medicina Preventiva que, digamos assim, seria a Filosofia da Medicina, aquilo que é de lado, que é marginalizado, não veem propriamente como ciência. Era uma coisa do tipo "médico que gostaria de ser sociólogo", mas por engano virou médico e agora ele quer fazer essas coisas, quer trabalhar com as pessoas, quer melhorar a vida das pessoas e tal, os outros (médicos) veem isso com muito desprezo. Mas esse pessoal, por conta dessa vocação que realmente têm, digamos sanitarista, que 
tem a ver com o urbano, com a cidade, tem a ver com a dimensão social, eles foram se preocupando com questóes éticas. Eu me lembro que eu e outros professores da Ciências Sociais, Irene Cardoso e outras pessoas também, fomos chamados lá para fazer reunião com eles, para opinar e tal, uma coisa bastante informal, não podia ser de outra forma, porque eles não tinham condiçóes de desenvolver um trabalho sistemático e não chegava aos alunos também. Não chegava aos alunos, porque a formação dos alunos não permitia essas interferências e os próprios alunos não estavam interessados, eles já tinham aquela mentalidade médica positiva.

Mas isso foi se desenvolvendo, o Conselho Federal e o Conselho Estadual foram cada vez mais se comprometendo com isso, formaram-se grupos mais organizados, revistas, até que se chegou à situação de hoje, em que você tem uma pós-graduação com mestrado e doutorado em Bioética, não é na USP, porque a USP ainda não aceitaria uma coisa dessas, é numa faculdade particular dedicada a questôes de saúde, que é a São Camilo, tradicionalmente ligada a questóes de saúde. Eles permitiram que se fizesse lá, mas antes disso houve várias tentativas na CAPES de fazer na UNESP e na USP, nunca deu certo, porque há uma resistência muito grande dos médicos a esse tipo de coisa, mas pelo menos agora são permitidas as discussôes, os alunos têm algum acesso a isso, têm algumas aulas sobre isso, há cursos de difusão sistematicamente ministrados, os alunos são convidados a fazer, os recém-formados e aqueles que já estão na situação profissional podem fazer mestrado e doutorado em assunto de Bioética, pelo menos aqui em São Paulo e em Brasília; parece que são os únicos dois lugares onde existe curso desse tipo. Eu colaboro desde o princípio com eles, eles me chamam para todas as essas iniciativas; eu dou aula, dou palestras, escrevo artigos; daí os títulos que aparecem no meu currículo relativos a esses temas, mas eu repito, eu procuro sempre levar, que é o que eu posso fazer também, a História da Filosofia para isso. Por exemplo, há uma disciplina na São Camilo que eu ministro, cujo título é "Correntes filosóficas fundamentais da Bioética", "Fundamentos da Bioética”; consiste em falar de Ética, mostrar aos alunos como se passa da Ética à Bioética, uma Ética aplicada, para eles saberem quais são os fundamentos, pelo menos algumas correntes, Aristóteles, Kant, uma visão panorâmica, para eles terem ideia do que significa a Bioética e sobre uma certa crise ética que produziu essas éticas mais particularizadas. Eu procuro levá-los a essa reflexão e escrevo também sobre isso, às vezes até com temas aparentemente bastante circunscritos, como essa coisa do Biofilho e essas preocupaçóes que eles têm sobre o fim da vida, começo da vida, células-tronco. Não trato desses temas, 
porque eu não tenho competência, fico mais com essa parte de fundamentação ética dos dilemas que eles têm, sem chegar àquilo que para eles é realmente importante; por isso, acho que a Filosofia vai acabar se afastando disso também, eles vão perder a paciência, porque não chega aonde eles gostariam, que é a decisão. Digo para eles: a decisão é fruto de uma reflexão. Se você, através de um panorama histórico, de um conhecimento da Ética, dos problemas éticos, aprender a refletir sobre isso, você vai refletir sobre os seus problemas que são aparentemente particulares, mas que têm a ver com coisas mais universais, mas eles não têm paciência para isso, eles gostariam de uma coisa que fosse mais prescritiva, mais normativa, menos reflexiva, o que eles têm em outras disciplinas sobre esses assuntos específicos. Eu sempre digo para eles: vai acontecer com vocês o que aconteceu com todas as outras ciências, vão se separar da Filosofia.

\section{Clélia - E sobre religião e sociedade pós-secular?}

Franklin - Tem a ver com minha preocupação com o existencialismo cristão, Kierkegaard, Gabriel Marcel, Pascal. Desde Pascal que pode ser considerada essa linhagem; eu estudei esses autores, alguns mais profundamente, outros mais superficialmente, e escrevi alguma coisa, formulei alguma coisa nesse sentido, acredito que por causa disso eu fui chamado para participar de alguns eventos relativos à Filosofia e Teologia e mesmo até Teologia. Participei de eventos na UNISINOS, na área de Filosofia e de Teologia, e também lá no Sul, onde há vários seminários importantes de ótimo nível, protestantes também, que me chamaram para participar. Eu acredito que, por eu transitar um pouco nessa questão de Cristianismo e religião, eu tive a oportunidade então de estudar essas questôes. Para entender Pascal, tive que estudar um pouco de Teologia, o que está principalmente num texto "O mediador e a solidão", que saiu publicado na Revista Cult, um texto mais ou menos longo, saiu num livro organizado pelos beneditinos, o qual é sobre a figura de Jesus, e eu falei dum texto do Pascal sobre a questão da solidão do Cristo e da solidão humana, que é bastante teológico esse texto de Pascal. Então, eu tive que me instruir em assuntos de Teologia, nessa fronteira aí, para tratar dessas coisas e por conta disso fiz exposiçôes, algumas delas foram publicadas depois em revistas ou em livros principalmente nesses lugares UNISINOS e seminários de Teologia lá no Sul, em escolas de Teologia lá do Sul, onde há luteranos e tal. Aqui em São Paulo tive pouca chance de fazer essas coisas, mas, digamos assim, não é uma linha de pesquisa que eu tenho e sim é um interesse que eu tive que desenvolver, por conta de um melhor aprofundamento, principalmente 
por causa de Pascal; durante algum tempo, eu pesquisei mesmo, de maneira sistemática, tenho uns quatro ou cinco ensaios sobre Pascal que são frutos desse meu empenho sistemático, durante alguns anos, em compreender Pascal nesses termos da relação entre Filosofia e o Cristianismo, por isso, eu me encaminhei para esses assuntos. Daí a presença desses temas no meu currículo.

\section{Andrey - E sobre a técnica?}

Franklin - Então, foi essa coisa de oportunidade. Uma vez, numa entrevista, o Sartre disse uma frase que desconcertou os entrevistadores; ele disse o seguinte: "Eu só trabalho por encomenda". Mas é verdade, é isso, convites que me fazem para participação. Quando eu era um jovem estudante, o Heidegger e o Nietzsche eram as obsessóes de todo mundo e eu passei por isso, estudei muito, tive aulas e não se podia passar sem isso, na minha geração. Por conta disso, falei também nas minhas aulas um pouco e tal e a partir daí eu tive esse convite que foi do Pablo, se eu não me engano, e do Marco Aurélio Werle, que estavam organizando a tradução do ensaio do Heidegger sobre a técnica e queriam que fosse precedido de uma introdução, a qual seria objeto de uma exposição que eles fariam lá para o lançamento. Fiz a tal exposição que eles me pediram e foi publicada então como a introdução ao ensaio do Heidegger sobre a técnica. É claro que o meu conhecimento do Heidegger é superficial, porque eu não entendo alemão, então, eu sou obrigado a fazer aquelas coisas que nesse caso se faz: ficar analisando palavra por palavra, porque no Heidegger isso é importante para saber aonde se chega com aquilo, mas não muitas, porque não seria possível. Assim, durante algum tempo eu me dediquei a esses estudos, tenho alguma familiaridade com os textos de Heidegger a partir da tradução. Fiz esse estudo que me foi encomendado e, nesse caso, o ensaio sobre a técnica, considerei um pouco o contexto histórico, porque isso também coincidia com outros textos que eu escrevi a propósito da Bioética para entender uma coisa, que no caso dos médicos é um problema com que eles não estão conseguindo lidar muito bem, que é a tecnologia médica, a tecnologia médica que praticamente assumiu o lugar do médico. Hoje em dia, se você vai a um médico ele praticamente não faz nada, ele é só intermediário entre você e os exames que você vai fazer nas máquinas, ele mesmo não participa grande coisa disso, e os médicos quando eu digo isso me falam que eu sou do tipo da medicina romântica que o médico ficava apalpando o doente, conversando com o doente, isso aí é medicina romântica, hoje em dia você tem computador, você tem aquele monte de máquina, não há por que agora conversar com o paciente. Eu discuto essas coisas com eles 
e, por conta disso, eu sou obrigado a falar para eles da origem da técnica, da origem da tecnologia; o que isso representa em termos de cultura, de progresso científico, a ambivalência da técnica, coloco esses problemas para eles. Então, já venho há algum tempo fazendo isso, talvez por isso o Marco Aurélio e o Pablo tenham achado que eu poderia fazer esse ensaio sobre o Heidegger, porque eu realmente uso também nesses meus outros escritos e aulas sobre a questão da técnica, da relação entre técnica e ciência e a presença da tecnologia, as ambiguidades, os problemas que isso traz. Nas revistas de Bioética, há alguns artigos sobre isso e, no caso da Filosofia, essa minha introduçâo ao texto do Heidegger.

Clélia - O senhor produz bastante em Bergson, Sartre, além de Heidegger e Merleau-Ponty. O senhor poderia nos dizer um pouco dessas pesquisas, as temáticas que o senhor aborda em cada uma delas?

Franklin - Eu acho que a minha vida acadêmica pode se dividir em dois eixos de pesquisa; o primeiro deles foi o Bergson. Eu fiz o mestrado, o doutorado e a livre-docência com temas em Bergson. No caso do doutorado, eu saí um pouco fora estritamente do Bergson e tentei fazer uma contextualização do período em que o Bergson pensou ali o ponto de vista filosófico, sociológico, para entender a Filosofia moral, como uma preparação para entender a ética do Bergson. O doutorado foi mais isso, mas o mestrado foi um ponto bem definido, a psicologia no caso de Bergson, e a livre-docência foi a intuição e o discurso filosófico, um ponto bem localizado.

Isso demonstra o quanto, durante boa parte da minha vida, estive às voltas com Bergson, os seus textos, os seus comentários e tal. Escrevi e dei cursos sobre isso. Depois, passei para uma outra linha de pesquisa, que é aquela em que até hoje estou mais ou menos na medida em que tenho ainda alguma coisa a ver com pesquisa. Estou tentando seguir, que é Sartre; tenho estudado aspectos do Sartre, principalmente relativos à relação entre subjetividade e história, mas para isso percorri vários aspectos do pensamento do Sartre do ponto de vista filosófico e literário, do qual resultou aquele livro Ensaio sobre a Ética em Sartre, alguma coisa assim, Etica e Literatura em Sartre, que foi publicado pela UNESP. Esse livro condensou um pouco as pesquisas que eu fiz a partir desse período e agora já está na fase das provas. Portanto, deve sair no começo do ano que vem um pequeno livro sobre o humanismo em Sartre, que faz parte de uma coleção que o Professor Milton idealizou, publicada pela Humanitas, em colaboraçáo com a Barcarolla. São pequenos livros sobre temas em autores filosóficos; eu resolvi escrever sobre o humanismo em Sartre, 
uma coisa da qual se fala muito por causa da famosa conferência, mas à qual se dedica pouco estudo, no sentido de apanhar mesmo o que seria isso, uma coisa fácil, um livro de cento e trinta, cento e quarenta páginas no qual procuro focalizar o [humanismo] no Sartre. Esse livro, digamos assim, do ponto de vista da divulgação, é meu último resultado de pesquisa. Em termos de artigos e cursos, eu tenho seguido essa linha de tentar explorar aquilo que seria a sua Filosofia da História, uma Filosofia existencialista da História, a qual durante muito tempo foi considerada contraditória e paradoxal, mas que existe; o Sartre fez ou tentou fazê-la e exploro isso através da análise que desenvolvi nos últimos anos dessa relação entre subjetividade, existência subjetiva e História.

Clélia - E como o senhor vê a pesquisa em contemporânea hoje? E a pesquisa em contemporânea há vinte, trinta anos atrás, quando praticamente era uma fonte nascente, quer dizer, contemporânea do início do século XX ou meados do século XX e a contemporânea hoje, no século XXI, tem uma leitura diferenciada? $A$ impressão é que são abordagens diferenciadas, ou não?

Andrey - Uma outra coisa: a filosofia contemporânea é própria só século XX ou também faz parte do XIX?

\section{Clélia - Esse é um dilema, não?}

Franklin - Essa questão, digamos assim, acho que só pode ser resolvida convencionalmente. Engraçado, quando nós éramos estudantes, eu e minha turma nos preocupávamos com isso e a gente dizia assim: "Mas como faz a divisão aí, inclusive para interferir na grade didática, quando se considera que é moderna? Quando se considera que é contemporânea?” Naquele tempo, a convenção era a seguinte: o ponto divisório é Hegel, que pode ser considerado tanto moderno quanto contemporâneo, dependendo da leitura que você faz em relação àquilo que ele fez a partir de Kant ou então aquilo que ele proporcionou ao Marx; conforme você o lê, ele é moderno ou contemporâneo. Então, ele seria aí um marco divisor que adotávamos e até hoje, quando tenho que fazer algum programa ou algo mais sistemático, eu adoto essa convenção de que contemporânea é a filosofia que veio depois de Hegel e, portanto, é um sentido amplo de contemporâneo. Muita gente implicaria com o fato de que o que veio depois do Hegel ainda tenha muitas vezes um teor ainda quase clássico, alguns autores, portanto, não seriam propriamente contemporâneos. $\mathrm{Eu}$, porém, acho que é uma divisão razoável senão do ponto de vista de abarcar uma uniformidade de estilo, pelo menos de certos nascimentos de temas que, a partir de Hegel, certamente acontecerem, disso ninguém duvida. Outros 
temas, necessidade de pensar com um outro estilo, isso aí não há dúvida de que houve, logo uma diferença que marcamos como sendo mais contemporâneo.

É claro que se você chega então a essa reflexâo sobre o pós-moderno, você tem aí uma contemporaneidade mais de acordo com uma experiência imediata do contemporâneo, as crises que a gente vive e tal. Chamar só isso de contemporâneo me parece um pouco restritivo, porque isso também surge a partir de uma certa gênese que já está lá no final do XIX, na segunda metade do XIX, e que vem por aí afora. Agora, o fato é que são demarcaçôes convencionais. O próprio Bergson, enquanto um filósofo que faleceu em 1941, tem muito de clássico, ele tem preocupaçóes que são quase que cartesianas, embora ele as veja de outra forma. Portanto, isso tudo é muito relativo.

Penso que o advento da USP proporcionou ao estudo do pensamento contemporâneo esse mesmo rigor que havia em relação a outras épocas históricas e deixou de existir algo que havia muito antigamente e é muito facilitador, e isso até hoje às vezes ocorre: por ser contemporâneo, você dispensa um pouco a compreensão rigorosa do texto e parte logo para uma polêmica ou para uma adesão. Isso aconteceu com vários autores contemporâneos. O Heidegger é um exemplo: tem muita gente que concorda plenamente ou discorda plenamente, sem entender muito bem o que está ali. Tenho a impressão de que a exigência de rigor que está no estudo contemporâneo vem daí e isso é muito marcante na USP, no caso, por exemplo, do Bento Prado, que foi um dos primeiros a se aventurar nesse tipo de coisa, porque antes se fazia isso com Descartes, com Spinoza, com Marx e com outros autores que têm um sentido histórico mais bem definido. Agora, com alguma coisa que nos toca por ser já muito próximo de nós isso é mais difícil; nesse caso, o livro do Bento Prado sobre Bergson é um modelo de análise de texto e ao mesmo tempo de reflexão. Ele é interessante nesse sentido e é o que eu procurei também, dentro das minhas limitaçóes, fazer com o Sartre, quando eu passei a usar o Sartre, também tendo em vista essa perspectiva, apesar de ser um contemporâneo quase aí perto de nós, mas lê-lo não como um clássico, mas como um texto de filosofia com a sua lógica própria rigorosa, o que é recomendação do próprio Sartre, quando ele diz que o existencialismo virou moda, porque as pessoas não leram - se tivessem lido, teria ficado algo meio difícil.

Creio que a filosofia contemporânea hoje em dia se beneficia muito dessa tradição que se formou, e você pode perceber bem que há uma área de contemporânea bem desenvolvida, os estudos sobre Hegel até o Heidegger, Sartre, passando pelo Paul Ricoeur, Levinas e outros autores, Habermas e 
outros; eles se pautam por essa tentativa de apreender a lógica do texto filosófico antes de você poder opinar se o camarada está certo ou está errado, se aquilo é viável ou não é. Entendo que isso é perfeitamente normal e necessário, quando se trata de um contemporâneo, o filósofo está tratando de coisas com as quais você também está. Por exemplo, discutir com o Habermas é importante, mas desde que o texto dele tenha passado pelo crivo de uma leitura filosófica rigorosa, porque senão você discute as ideias dele de uma maneira vaga, as intençóes mais do que o texto. Náo precisa ter, digamos assim, aquela veneração como se fosse uma doutrina, mas isso em relaçáo a ninguém você precisa ter, mas a discussão tem que ser baseada apenas num entendimento orgânico do texto. Penso que, de uns tempos pra cá, os estudos de filosofia contemporânea ganharam muito com esse rigor. Estudos contemporâneos que tenho lido, atualmente eu estou dando um curso sobre Levinas e estou muito em contato com os estudos sobre esse período pós-fenomenológico que Levinas, MerleauPonty e outros representam táo bem, e pelos textos a que eu tenho acesso do pessoal que estuda isso no Brasil e fora você percebe que a análise é feita de uma maneira bem arquitetada, de uma forma muito rigorosa e esclarecedora mesmo dos textos, sem prejuízo de uma discussão que você pode encetar com o autor, tendo em vista que ele está falando de nossa vida praticamente.

Clélia - Professor Franklin, no medievo eu acho que a gente tinha a alma iluminada, na moderna, é um eu ou uma consciência que pode conhecer o mundo. Agora, na contemporânea, você tem uma crítica à filosofia do sujeito, o sujeito é um pós-sujeito, uma multiplicidade de vozes e, paralelo a isso, a essa acepção de um homem que não é único, o individuo por si mesmo, mas é múltiplo, há uma ascensão, uma valorização muito forte da linguagem, da filosofia da linguagem, desde meados do século passado. Como o senhor vê isso em termos de História da Filosofia, quer dizer, essa tematização que vai descaracterizando o homem ou a consciência, a força da consciência, diante também, e paralelo a isso fortalecendo, centralizando, focando pesquisas e reflexóes em torno da linguagem; ninguém conversa sozinho, em Wittgenstein isso é o óbvio, então, e paralelo a uma sociedade de massa que se constitui mundialmente e que tem a ver com o ser humano, tem que sustentar o que é o humano diante dessa multiplicidade de seres que podem não pensar ou não falam, mas que tem que existir como humano. Como o senhor vê essa relação entre esses temas da Filosofia contemporânea e as transformaçóes do mundo?

Franklin - Vejo que há certo paralelismo, embora não uma conexão intencional entre a virada linguística, tal como a Filosofia anglo-saxã promove, e as reflexóes da morte do sujeito, que vem principalmente com Foucault. Eu 
acho que há um paralelismo entre isso, porque na verdade a procura de certa substância de significação na linguagem tem a ver com essa ideia de que aquilo que é dito, a linguagem, as palavras, funciona como uma instância lógica para a qual você não precisa supor um sujeito metafísico. Isso está bem de acordo, digamos assim, com algumas tendências de filosofia analítica de não levar em conta uma reflexão ligada a essas questôes metafísicas. Por outro lado, também essa instância de linguagem, essa instância lógica da qual emana a linguagem, que não deixa de ser uma certa voz, no meu entender, ela é a tentativa de encontrar ainda uma certa instância de unidade que não é mais nem metafísica nem formal, como no caso de Descartes e de Kant, mas funciona ainda, digamos, no estilo transcendental. Embora muitos filósofos analíticos não admitam isso, acho que há ainda uma sobrevivência do transcendental ao sujeito cartesiano ou ao sujeito kantiano e que acabou se fixando na linguagem. Na filosofia inglesa tem muito a ver com isso. No caso dos franceses e dos alemáes, em que a herança de temas que se tornaram inevitáveis do ponto de vista não só do sujeito, da perda do sujeito, mas também da questão da intersubjetividade que você colocou, isso faz com que as coisas funcionem de outra forma, quer dizer, não apenas uma linguagem, uma comunicação em instância lógica, instância lógico-linguística, mas a questão do indivíduo, a questão do sujeito. Você tem essa vertente que, penso, está também em paralelo, que procura refletir sobre alguma coisa sobre a qual o professor Bento gostava muito de dizer; ele dizia: há muitos temas que vivem de sua própria morte; quanto mais vocês falam que eles estão mortos, mais se reflete sobre eles. E o Nietzsche já havia dito isso a respeito da morte de Deus, falar da morte de Deus é um modo de falar de Deus e o sujeito então passa um pouco por isto nessa vertente principalmente francesa. A maior prova disso é a trajetória do próprio Foucault, que em $A s$ palavras e as coisas tem aquela espécie de anti-humanismo que parece ser uma reação à filosofia da subjetividade e depois, no final de sua obra, encontra possibilidades subjetivas que não são aquele sujeito clássico, mas que refletem a procura ainda de um sujeito, o que quer que ele seja. Eu acho que essa problemática transparece na filosofia contemporânea e dentro de uma linha que eu acho importante salientar, náo tanto a questão do conhecimento, na qual parece que as prerrogativas do sujeito realmente foram esgotadas, mas do ponto de vista ético-histórico, quer dizer, é sintomático que o Foucault tenha abandonado o sujeito epistemológico e depois reencontrado um sujeito ético, no final da obra. Creio que isso acontece de uma maneira ou de outra em muitos autores, por exemplo, a maneira pela qual o Paul Ricoeur dá o tratamento da questão do sujeito é predominantemente ético e, sobretudo, 
o caso extremo é o Levinas, que propõe que se substitua a questão do sujeito no sentido do ego por aquilo que o Descartes achava impossível, que é você considerar que o outro seja sujeito. Descartes achava impossível, inclusive, a reflexão encontrar o outro da mesma forma que encontra a si próprio, mas Levinas coloca essa questão, ou seja, existe uma espécie de crítica da posição do sujeito; e essa posição do sujeito, no entanto, não é para que desapareça todo e qualquer sujeito, mas para que se estabeleça uma relação em que o princípio se tornou diverso, por exemplo, o princípio do outro, a minha relação com o outro e a minha relação com o mundo não sou mais eu, deveria ser o outro, o outro é o princípio, o outro é a diretriz, o outro é o centro, o desencadeador.

\section{Clélia - É o descentramento do eu.}

Franklin - Eu acho que o descentramento do eu, de um lado, produziu a fragmentação e, de outro lado, produziu também essa ideia de que já que o sujeito está agora descentrado, vamos tentar encontrar aquilo com que nunca se preocupou seriamente, que é o outro, e isso então faz com que haja um deslocamento da Lógica, da Teoria do Conhecimento, do modelo cartesiano tradicional, para a Ética - e isso tem a ver, é claro, com a crise contemporânea, a crise contemporânea das relaçóes humanas. Então, temos a tentativa de você reencontrar uma nova posição de um sujeito constituído eticamente, e não como você precisasse constituí-lo primeiro logicamente e depois subsidiariamente como ético, como concebia a filosofia tradicional, que é a platônica; se você não conhece, você não age, se você não conhece o bem, você não faz o bem. Talvez se procure até inverter a coisa, quer dizer, o sujeito começa por uma conduta ética, depois ele vai se conhecer, conhece as coisas, conhece o outro, mas essa conduta ética já inclui o outro, se é ética, já inclui o outro, se é ética, é política, então, inclui o outro. Isso, digamos assim, num mundo em crise como o nosso, é algo importante, não sei qual vai ser o destino dessa perspectiva, se ela vai proliferar ou não, se ela vai interferir, se ela vai ser suficiente até para superar os hábitos tradicionais de pensamento, que são da ordem lógica e cognitiva, mas é importante assinalar que isso está acontecendo e que representa uma tentativa de, como diz o Levinas, tornar a ética primordial e ver o que acontece. Já que o conhecimento foi visto como primordial e não deu certo, vamos pensar que a ética é primordial e ver a partir daí o que se pode fazer.

Clélia - Isso me lembra Habermas, ele tem uma teoria da evolução baseada nessa noçâo de descentramento do eu, e ele tem também uma ética do discurso. Mas, voltando agora a outro aspecto do seu currículo: o senhor tem uma vasta 
participação em bancas, quer dizer, uma vasta produçāo quantitativa, sessenta e seis artigos em periódicos, quarenta e três artigos em jornal, seis livros publicados, trinta e dois capitulos de livros, cento e vinte bancas de doutorado, noventa e três bancas de mestrado - e aqui não estão sendo consideradas, porque não acusa no Lattes, a banca que o senhor participou comigo, outras nas quais o senhor participou na UNESP, na UFSCar, que a gente sabe que o senhor participou, lá não consta, só tem as da USP, e assim mesmo são noventa e três. Imagina se colocasse tudo! Trinta e duas dissertaçôes de mestrado orientadas, mais quatro em andamento, quarenta teses de doutorado orientadas, mais três em andamento. Nossa! Como o senhor consegue tudo isso? O senhor tem sessenta e cinco anos, o senhor não tem cem, imagine se o senhor chegar aos cem na ativa, produzindo ainda. O que permite ao senhor ter uma dinâmica de trabalho täo intensa? Porque, para nós, para nossa geração, é muito intensa.

Franklin - Não é uma coisa extraordinária. Se vocês forem olhar o pessoal que tem mais ou menos a minha idade que tiveram uma participação efetiva na universidade, vocês vão ver que é por aí, porque é uma questão, como você diz, quantitativa.

\section{Clélia - Mas mesmo assim é muito.}

Franklin - Eu fiquei trinta e oito anos na USP. Ao longo de trinta e oito anos, isso é uma coisa natural, você entende? É natural, as coisas aparecem e você vai fazendo, é natural. Oriento desde 1981, entấo é muito tempo, daí essa quantidade enorme.

Clélia - Eu não sei, para nós isso é espantoso. Nós ficamos assustados quando vimos. O senhor trabalha aos finais de semana direto?

Franklin - Tem um dado aí. Olha, por exemplo, a Marilena Chauí. Tem um dado aí que é interessante, no caso dela mais do que eu. Houve um momento em que o Departamento de Filosofia da FFLCH-USP ficou muito desfalcado por conta das cassaçôes, nesse momento então os poucos professores que ficaram tiveram que assumir tudo. Eu ainda náo estava nessa época, mas eu digo para vocês que essas circunstâncias ajudam a entender por que, por exemplo, a Marilena orientou tanta tese sobre tantos assuntos diferenciados, porque, na verdade havia somente dois professores, era ela e o Porchat, porque os outros tinham ido embora, exilados ou aposentados. Quando nós fomos contratados, eu e meus colegas, essa situaçâo não se equilibrou facilmente. Portanto, quando eu comecei a orientar ainda havia essa ideia de que você náo pode se dedicar apenas a uma certa área que, digamos assim, seja um 
desdobramento daquilo que você faz, o que seria o ideal, porque você atuaria de maneira mais eficaz na sua orientação, se você tem uma afinidade de trabalho com um aluno, claro, mas naquele período isso não era possível, porque você ia deixar muita coisa de lado. Por isso, éramos obrigados a aceitar orientar muitas teses sobre assuntos muito diferentes. Agora, a partir de certo momento, as coisas começaram a se configurar melhor com uma divisão de trabalho mais equitativa, mas, no meu caso, um pouco continua esse hábito, essa disposição, e isso também tem a ver com a atitude que eu tenho em relação à orientaçáo. Para mim, orientação é uma coisa predominantemente institucional, você já foi minha aluna, você se lembra disso, não é? Eu acho que a orientação não é importante, em alguns casos até atrapalha.

Clélia - Mas o senhor orienta bem, programa leituras, cobra texto etc. numa sequência muito rigorosa.

Franklin - Eu acho que tudo isso é trabalho institucional, você dá o lugar institucional para o cara fazer o trabalho dele, ele tem que chegar ao fim, você tem que cobrar. Agora, orientar no sentido de acompanhar e palpitar e às vezes até ensinar, que por vezes se faz, eu nunca fiz isso. E acho que não é o caso, porque a pessoa faz ou não faz, e se ela não for capaz de fazer, o orientador não é capaz de fazê-la fazer, ele pode fazer por ela, mas, se a pessoa não pode fazer, não faz; entâo, acho que é principalmente institucional. Por exemplo, quando chega um assunto que eu conheço pouco eu às vezes conheço até longinquamente e tenho assim uma certa ideia de que o camarada é capaz de fazer aqui, porque ele já estudou, ele sabe o que ele vai fazer, tem um bom projeto, eu digo: "Faça”. E por isso a multiplicação numérica das teses e a variedade dos assuntos que aparecem.

\section{Clélia - É variado, mas tem um perfil.}

Franklin - É, tendo em vista essa necessidade de atender a muitas áreas que não estão devidamente contempladas, ou que até um tempo atrás não eram, e também esse meu entendimento de orientação que é um entendimento, digamos assim, que podemos considerar meio solto, mas é a maneira como eu vejo as coisas.

Clélia - Mas na orientação mesmo não é nada solto, tenho experiência própria, fui sua orientanda.

Franklin - É, na época em que você foi minha orientanda, eu ainda vigiava os prazos dos orientandos, hoje não faço mais isso. Há, contudo, algo 
que é demasiado, eu reconheço, além da conta, que é participação em bancas, eu nem sabia o que constava do Lattes, porque eu não costumo entregar os certificados para quem registra para mim.

Clélia - Noventa e três bancas de mestrado e cento e vinte e cinco de doutorado, de fora há o registro de uma ou outra, mas em geral todas sáo apenas na USP.

Franklin - E eu participo muito fora da USP.

Clélia - Então, imagine, isso deve ir pra quase 200.

Franklin - Muito na PUC.

Clélia - E nem consta lá.

Franklin - Porque me esqueço de entregar as declarações. E também para não aumentar muito isso aí. É muita coisa já e isso nem é virtude, isso é uma certa desorganização da capacidade de discernimento entre o sim e o náo.

Clélia - Ele é sempre assim - tão humilde...

Franklin - Não, não e não. Por que é que eu estou nessa situação depois de aposentado? Porque eu não tenho discernimento entre o sim e o não, aquela coisa que o Aristóteles falava, razão prática, quando dizer sim e quando dizer não.

Clélia - Eu não sei, toda banca que ele vai ele leva um texto como arguição.

Franklin - Então, eu tenho realmente muita participação em banca, porque eu não consigo ter esse discernimento entre aquilo que me convém fazer por conta de interesses e tal e outros que eu poderia não fazer.

Clélia - Ou talvez porque o senhor não tenha coragem de dizer não.

Franklin - Entáo, isso aí é a falta do discernimento. E aí o que acontece? A pessoa adquire certa reputação, e há dois tipos nesse caso, aquele que você não deve chamar porque pode dar problema e aquele que você pode chamar. Eu para o bem e para o mal, fiquei nessa última, a reputação daqueles que eles podem chamar. Devido a isso me chamam muito na USP e fora da USP, e aí acumularam desse jeito, de modo que realmente é uma coisa quantitativamente impressionante e, seguramente, muito além daquilo que se poderia fazer razoavelmente, eu reconheço isso. 
Clélia - Não, isso de forma alguma foi focado para a questão do razoavelmente bem, de forma alguma. Isso só consolida uma trajetória de muita qualidade de trabalho. Como orientanda, mas também já participei de uma banca sobre Nietzsche com o senhor, ocorrida na reitoria na UNESP, e de uma banca de um aluno meu em Deleuze, e foram excelentes as arguiçöes do senhor. Eu acho que isso só consolida a qualidade. Mas o número é realmente alto e nos assusta, como consegue ser tão disciplinado, tão flexivel para manter tanta atividade?

Andrey - O senhor começou muito cedo, não?

Franklin - Sim, e as circunstâncias também de trabalho pouco distribuído no início, se você pega o pessoal daquela época você vai ver coisa semelhante; ocorre que muitos deles, assim que a situação melhorou, tiveram discernimento e passaram a delimitar, eu não atingi esse grau de razoabilidade.

Clélia - Então espero que não atinja. 
